\title{
Association of Diabetes Mellitus and Thyroid Disorders: An Adipocytokines Prospective
}

\author{
Manish Mishra1* ${ }^{1 *}$ Raju Panta ${ }^{2}$, Miguel Miyares $^{1}$, Ranjan Solanki ${ }^{3}$ \\ ${ }^{1}$ Department of Biochemistry and Genetics, Trinity School of Medicine, St. Vincent and the Grenadines \\ ${ }^{2}$ Department of Physiology, Trinity School of Medicine, St. Vincent and the Grenadines \\ ${ }^{3}$ Department of Pathology, Trinity School of Medicine, St. Vincent and the Grenadines
}

Submission: March 27, 2018; Published: April 16, 2018

*Corresponding author: Manish Mishra, Associate Professor, Department of Biochemistry and Genetics, Trinity School of Medicine, Ratho Mill, St. Vincent and the Grenadines, Tel: +1-784-492-5497; Email: mmishra@trinityschoolofmedicine.org/nmcmanish@gmail.com

\begin{abstract}
The world health organization (WHO) reported the prevalence of diabetes is $8.5 \%$ and The Third National Health and Nutrition Examination Survey (NHANES III) reported the prevalence of thyroid disorders; hypothyroidism and hyperthyroidism to be $4.6 \%$ and $1.3 \%$ respectively. These two endocrinopathies often coincide and commonly affect each other due to shared atypical biochemical pathways, abnormal hormonal action and aberrant expression of several genes. The various adipocytokines may control the metabolic pathways, feeding, neuro-endocrine secretion, thermogenesis and even immunity. The dysfunctional adipocytokine pathways have been noted to be key etiological cause for different metabolic syndromes and obesity-related disorders. Thyroid disorders and diabetes mellitus, both of them known for variation in body weight, insulin sensitivity, adipocyte metabolism and altered secretion of adipocytokines. The variance in adipocytokines in both aforesaid endocrinopathies may be the causative agents for respective idiosyncrasy. In this review article we emphasized the role of adipocytokines on diabetes and thyroid disorders.
\end{abstract}

Keywords: Diabetes mellitus; Hyperthyroidism; Hypothyroidism; Adiponectin; Leptin; Ghrelin; Resistin; Visfantin; Vaspin; Obestatin

\section{Introduction}

Diabetes mellitus (DM) and thyroid disorders (TD) are the two foremost common endocrinopathies, which often coexist and mutually influence each other. Numerous research studies have reported the alliance among DM and TD [1-6], and confirmed diverse multifaceted associations involving abnormal biochemical pathways, aberrant genetic expressions and hormonal malfunctions, explaining their pathophysiological association [6-8].

The role of autoimmunity in the progression of TD has been observed amongst the type 1 diabetes mellitus (T1DM) and autoimmune thyroid disease [9]. An association between thyroid dysfunction and type 2 diabetes mellitus (T2DM) has also been recommended, but the potential causative mechanisms are intricate [10].

The most plausible mechanism for advancement of T2DM in patients with thyroid dysfunction could be due to disturbed genetic expression of several genes in conjunction with physiological aberrations leading to impaired glucose consumption by the muscles, augmented hepatic glucose output, and higher glucose absorption from intestine [6]. These endocrine disorders impact each other in a variety of ways. Thyroid hormones (TH) contribute to the regulation of carbohydrate metabolism and pancreatic function, and on the contrary, diabetes affects thyroid function tests to variable extents $[1,5]$.

Altered plasma triiodothyronine (T3) and thyroxine (T4) levels have been noted in poorly controlled diabetic patients [11]. To clarify the link between DM and TD, the association of Hashimoto's thyroiditis (Hypothyroidism) and Graves' disease (thyroid over activity) has been explored in reference to DM. The consequence of hyperinsulinemia/insulin resistance, in thyroid cell proliferation, which manifested as increased thyroid volume and nodule have been also observed [12-14].

\section{Prevalence}

A predicted 422 million adult population had diabetes in 2014 worldwide, as compared to 108 million in 1980. If compared to 1980 's the prevalence of diabetes has nearly doubled, growing from $4.7 \%$ to $8.5 \%$. It increased more rapidly in low and middle-income countries than developed countries [15,16]. As per National Diabetes Statistics Report 2017, 30.3 million Americans (9.4\% of the population), were living with diabetes in 2015 [17,18]. 
Thyroid disorder is another common endocrinopathy with variable prevalence [1,2]. Wang and Crapo in 1997 reported that as many as $50 \%$ of the community have microscopic nodules, $3.5 \%$ have occult papillary carcinoma, $15 \%$ have palpable goiters, 10\% exhibit an abnormal thyroid-stimulating hormone (TSH) level and 5\% of women have overt hypothyroidism or hyperthyroidism [19]. Wickham survey reported the thyroid dysfunction in $6.6 \%$ of adult males in UK [20] while Colorado prevalence study reported that the $9.5 \%$ of population had elevated TSH and $2.2 \%$ had low TSH [3]. As per the National Health and Nutrition Examination Survey (NHANES III Study), hypothyroidism and hyperthyroidism were reported in $4.6 \%$ and $1.3 \%$ respectively in the total participants [21]. According to Framingham study thyroid deficiency in $4.4 \%$ of elderly men and women (overt 60 years of age) had been reported [22]. Perros et al. reported that the occurrence of thyroid dysfunction increases with age all over the world, and the frequency of occurrence was higher in women than men [23]. In Germany, thyroid nodules or goiter were reported in $33 \%$ out of 96,278 working adults (aged 18-65 years), screened by an ultrasonography [24].

As per NHANES III survey observed the higher occurrence of thyroid disease in diabetic subjects as compared to non-diabetics [21]. The incidences of thyroid disease in diabetic subjects were reported to be $13.4 \%$, and were maximum in T1DM females (31.4\%) and minimum in T2DM males (6.9\%) [23]. The Greek study reported $12.3 \%$ prevalence of thyroid dysfunction among T2DM, with higher extent in females than males [25]. The Jordan study also observed approximately same prevalence $(12.5 \%)$ in T2DM patients [26]. As per Chaker et al. the higher TSH levels were linked with a higher diabetes risk. The non-diabetics have 1.09 times while pre-diabetes have 1.13 times higher risk for developing diabetes with every doubling of TSH levels [2]. The prevalence of subclinical hypothyroidism ( $\mathrm{SCH}$ ) was reported to be approximately $2 \%$ [27] and in T2DM patients about $10.2 \%$ [27-29]. Han et al. observed that the T2DM was linked with a 1.93 fold increase in risk of SCH. Among T2DM patients, the women had 1.7 times higher occurrence of SCH than men while elderly T2DM (over 60 years of age) were reported to experience SCH associated risks more frequently [27].

\section{Adipocytokines}

Adipose tissue acts as an endocrine organ by secreting multiple immune-modulatory proteins recognized as adipocytokine. Obesity causes increased expression of proinflammatory adipocytokine and reduced expression of antiinflammatory adipocytokine, resulting in the development of a chronic, low-grade inflammatory state [30]. Atypical adipocytokine pathways have been recognized as a main etiological factor for obesity-induced disorders. In last two decades, several adipocytokines were identified as critical regulators of systemic lipid and glucose homeostasis, and the list continues to grow. Adipocytokines mediate the crosstalk between adipose tissue and other key metabolic organs, especially the liver, muscle, and pancreas, as well as the central nerve system. This adipocytokines imbalance is thought to be a key event in promoting different metabolic dysfunctions [31]. Patients with thyroid dysfunction and diabetes mellitus exhibit changes in body weight, insulin sensitivity, adipose tissue metabolism and production of adipocytokines [32-33].

\section{Adiponectin}

The adipocytokine, adiponectin is the most abundant gene (apM1) product and acknowledged for insulin-sensitizing, antiatherogenic, anti-diabetic and anti-inflammatory properties [5,34]. Binding of adiponectin hormone to the AdipoR1 receptor which is widely expressed in heart, skeletal muscles and moderately expressed in various tissues, activates the AMPactivated protein kinase (AMPK) signaling cascade that ultimately increases fatty acid oxidation, glucose uptake and decreases gluconeogenesis in liver. Binding of adiponectin hormone to the AdipoR2 which is ubiquitous in expression but avidly expressed in the liver, skeletal muscles and placenta, regulates peroxisome proliferator activated receptors - alpha (PPAR- $\alpha$ ) signaling cascade which ultimately increases fatty acid oxidation and glucose uptake [34-37]. The expression of adiponectin have reversible correlation with adiposity and insulin resistance [3840]. Adiponectin mediates insulin-sensitizing effect through binding to its receptors AdipoR1 and AdipoR2 [38]. Obese people reported to have lower level of adiponectin than lean subjects and weight loss significantly elevates plasma adiponectin levels [38,41]. The decreased levels of adiponectin are associated with insulin resistance, T2DM, dyslipidemia, atherosclerosis, hypertriglyceridemia, hypertension and metabolic syndromes in humans [42].

Adiponectin increases fT4 synthesis, due to interaction of C-terminal globular structure of adiponectin with $\mathrm{gC} 1 \mathrm{q}$ receptor present on mitochondrial membrane of thyroid cells [43]. Adiponectin and TH have similar physiological effects on metabolism like, reduction of body fat by increased thermogenesis and lipid oxidation [44], so it's believed that these hormones are associated with each other [45].

The inconsistent results were reported concerning the association between adiponectin levels and TH in experimental studies on hypothyroid/hyperthyroid animals. The serum adiponectins levels were reported to increased or unchanged in hypothyroid or hyperthyroid rats [46-48]. The levels of adiponectin mRNA in the adipose tissue were decreased in hypothyroid rats compared with controls, while in hyperthyroid rats, adipose adiponectin expression was increased in parallel with an increase in $\mathrm{TH}$, the opposite was observed in hypothyroid rats [49]. In contrast, Kokkinos et al. demonstrated increased adiponectin levels in hypothyroid rats, whereas no significant change was observed in the adiponectin levels after the administration of TH [46]. Cabanelas et al. observed that T3 administration in rats had no significant effect on adiponectin secretion in visceral (epididymal) and subcutaneous (inguinal) 
adipose tissues, while adiponectin mRNA expression was down regulated by $\mathrm{T} 3$ in the subcutaneous adipose tissue, but not in the visceral adipose tissue (VAT) [50]. In contrast, T3 administration was shown to increase adiponectin mRNA expression and release in a culture of mouse brown adipocytes [51].

In hypothyroid patients, reduced levels of adiponectin have been shown by Dimitriadis et al. [52], and comparable levels of adiponectin were observed in hypothyroid patients and controls in a study by Nagasaki et al. [53]. It was reported that adiponectin levels were higher in hyperthyroidism compared to hypothyroidism or euthyroidism, respectively $[54,55]$. Conversely Santini et al. and Iglesias et al. reported that adiponectin levels were not significantly different in hyperthyroidism when compared to control groups [56,57]. Altinova et al. could not be able to exhibit a relationship between thyroid status and adiponectin levels [58].

Seifi et al. demonstrated the decreased mRNA levels of adiponectin receptors, adipoR1 and adipoR2 in white adipose tissue (WAT) of hypothyroid rats, whereas mRNA levels of these receptors are increased in the hyperthyroid rats [59]. Adiponectin receptor gene expression levels in WAT showed positive correlations with $\mathrm{TH}$ concentrations, suggesting that AdipoR1 and AdipoR2 gene expression are regulated by $\mathrm{TH}$ in hypothyroidism and hyperthyroidism. Adiponectin gene expression was negatively correlated with low density lipoprotein and triglyceride levels in hypothyroid rats and positively correlated with glucose and high density lipoprotein levels in hyperthyroid rats. Taken together, TH may modulate lipid and carbohydrate metabolism via changes in adiponectin receptor expression in the adipose tissue [60]. The biological reason for increased plasma adiponectin levels in the adipose tissue in hyperthyroidism is unclear. Therefore, increased adiponectin levels might represent a compensatory mechanism against the insulin resistance observed in the hyperthyroid state [34].

\section{Leptin}

The other major adipocytokine is leptin, which increases in obesity and subcutaneous fat has been a major determinant of circulating leptin levels, as its level is positively correlated with body mass index (BMI), percentage of body fat, and insulin resistance (IR) indices such as homeostasis model assessment of insulin resistance (HOMA-IR) [38,61]. The leptin signal is transmitted by the Janus kinase, signal transducer and activator of transcription (JAK-STAT) pathway. The net action of leptin is to inhibit appetite, improve peripheral insulin sensitivity and modulate pancreatic $\beta$-cell function, stimulate thermogenesis, enhance fatty acid oxidation, and reduce body weight and fat $[38,62]$. A population based study in China by Zuo et al. suggested that there was a significant association between HOMA-IR and serum leptin concentrations independent to adiposity levels. Further they suggested that serum leptin concentration may be an important predictor for insulin resistance and other metabolic risks irrespective of obesity levels [63].

TH and leptin affect each other reciprocally, and may regulate body composition and metabolism through complex mechanisms $[32,64]$. Many studies demonstrated the correlation between leptin and TH but the results are conflicting. An increased serum leptin and insulin have been described in hypothyroidism [6567], while some studies reported decreased or unchanged leptin levels in hypothyroidism [57,68-70]. Similarly, inconsistent results have been reported in hyperthyroidism for increased, unchanged, and even decreased values of leptins $[67,70]$. Leptin, by enhancing the activity of type I iodothyronine 5-deiodinase enzyme, could result in an increase in circulating T3 level [71]. TSH stimulates leptin secretion by a direct effect on adipocytes, probably via TSH-receptors on the surface of adipocytes [72]. Serum $\mathrm{TH}$ also seems to affect leptin levels. However, in a study by Braclik et al. on serum leptin concentrations among premenopausal women with hyperthyroidism, hypothyroidism, or no thyroid dysfunction, leptin levels were similar before and after treatment of their abnormal thyroid status [73]. The changes in fat mass associated with thyroid diseases make it difficult to interpret the results of studies on leptin and thyroid dysfunction.

\section{Ghrelin}

Ghrelin, an orexigen, secreted from the fundus of the stomach, has been observed to exert its effects on appetite stimulation, energy homeostasis [5,74], and diabetes ameliorating effects including decreased secretion of the insulin sensitizing hormone adiponectin [75,76]. Ghrelin circulates in two different forms acylated and majorly circulating desacylated ghrelin. Ghrelin levels were reported to be decreased in obese, T2DM and hyperinsulinemia [77].

Hyperthyroidism generally causes weight loss despite increased caloric intake and induces negative energy balance [64]. Being a state of negative energy balance, hyperthyroidism should increase in ghrelin levels, but studies reported lower serum ghrelin levels in subjects with hyperthyroidism than euthyroids and its level increased to normal with treatment $[78,79]$. There are several suggested hypothesis for lower ghrelin levels observed in hyperthyroidism. In a hyperthyroid state, IR and compensatory hyperinsulinemia is induced [80]. Studies have shown that insulin may inhibit ghrelin secretion [80,81]. On the other hand, Broglio et al. and Tong et al. showed that acute administration of ghrelin caused an inhibitory effect on insulin secretion [82,83]. Although there has been a contradictory report by Amini et al. they investigated the association between circulating ghrelin and IR in a large population and observed the high circulating ghrelin is linked with lower IR in the general population, except in postmenopausal women [84]. Another possible explanation is that hyperthyroidism is associated with increased activity of the sympathetic nervous system and with 
abnormalities in the growth hormone/insulin like growth factor 1 axis, may affect glucose homeostasis, insulin sensitivity and ghrelin levels [64].

Increased levels of ghrelin have been observed in hypothyroid patients, and these levels returned to normal upon L-thyroxine treatment $[73,85]$. In hypothyroid rat models, increased circulating ghrelin and gastric ghrelin mRNA levels were demonstrated by Caminos et al. [86]. However, in some studies, hypothyroid patients were reported to have comparable ghrelin levels to that of healthy subjects and those levels were not significantly altered after TH replacement $[87,88]$.

\section{Resistin}

Resistin, which is synthesized in adipose tissue, bone marrow, lungs, muscle, pancreas, and macrophages, is believed to have a role in insulin resistance and obesity $[89,90]$. Several studies reported the augmented circulating resistin levels in obese diabetics and obese non-diabetics as compared to healthy non-obese subjects [91-93]. On the other hand some studies conferred with aforesaid observations and reported no correlation of serum resistin levels with blood glucose levels or obesity $[94,95]$. The serum resistin levels were also positively correlated with insulin levels and IR [91,92].

The association between thyroid diseases and resistin levels is controversial. Ziora et al. described a positive relationship between serum resistin levels and FT4 in anorexia nervosa patients [96]. Yaturu et al. measured the resistin levels in patients with Graves' disease before and after the treatment for hyperthyroidism. They reported that the concentrations of serum resistin were higher in hyperthyroid state than in hypothyroid state; and resistin levels correlate positively with free T4, free T3 levels and negatively with TSH [54]. Same way, El gawad et al. also reported higher serum resistin levels in hyperthyroid patients than control subjects and it's normalized after the treatment [79]. But, Iglesias et al. reported that serum resistin levels were similar in hypothyroid and euthyroid subjects [57]. Kaplan et al. demonstrated that no short-term significant changes in resistin, leptin, and adiponectin levels occurred in thyroidectomyinduced hypothyroidism when compared to the euthyroid state [68]. Another study showed a positive association between resistin levels and $\mathrm{TH}$ [54]. Alterations in resistin levels by other adipocytokines can be the reason for this conflicting data on resistin levels and thyroid status. It is suggested that changes in resistin levels can act as an adaptive mechanism in thyroid dysfunction [45].

\section{Visfatin}

Visfatin, a 52-kDa cytokine produced predominantly from macrophages and also from visceral adipocytes, leukocytes, hepatocytes and muscles [97,98]. Visfatin is expressed by the macrophages infiltrating adipose tissue in response to inflammatory signals $[99,100]$. This adipokine is identical to pre-B cell colony-enhancing factor (PBEF) and the enzyme nicotinamide phosphoribosyltransferase (Nampt) [101]. Increased circulating visfatin/Nampt levels have been reported in metabolic diseases, such as obesity, T2DM and the metabolic syndrome [102,103]. Nevertheless, there are conflicting results of visfatin/Nampt levels in these diseases being reported unmodified or lower compared to controls [104,105]. There is strong evidence that visfatin increases with obesity as demonstrated in a prospective cohort study, in which visfatin levels were augmented in morbidly obese subjects compared to normal-weight individuals. Visfatin normalized after 6 months of bariatric surgery and consequent weight loss [106]. Visfatin may play an important role in regulating insulin sensitivity in the liver [107]. Visfatin binds to the insulin receptor at a site distinct from insulin and exerts hypoglycemic effect by reducing glucose release from hepatocytes and stimulating glucose utilization in the peripheral tissues [108].

Mice heterozygous for mutations in the visfatin gene have glucose intolerance due to insulin secretion deficiency [109]. A negative correlation of visfatin levels with beta cell function was demonstrated [110]. Furthermore, continuous glucose infusion in humans acutely increases visfatin levels. This effect is suppressed by insulin or somatostatin infusion [111]. Brown et al. demonstrated that incubation with visfatin into mouse pancreatic beta-cells caused significant changes in the mRNA expression of key diabetes-related genes, including upregulation of hepatocyte nuclear factor 1 homeobox B (HNF1B). Visfatin also caused a significant increased secretion of insulin, activation of insulin receptor by phosphorylation by up-regulated extracellular signal-regulated kinase (ERK) $1 / 2$ compared to control and these functions were blocked by co-incubation with the specific visfatin inhibitor FK866 [112]. Chen et al. found a positive association between visfatin and the presence of T2DM in Chinese population [113]. Dogru et al. observed that visfatin levels were higher in the diabetic patients as compared to controls, but no significant difference were observed between pre-diabetics with controls [114]. Patients with long term T1DM and T2DM had higher visfatin levels compared to non-diabetic controls or recently diagnosed diabetic individuals [110].

The association of visfatin and TH were evaluated by some research groups. In clinical studies, Chu et al. observed that the hyperthyroid group had significantly higher plasma visfatin levels than controls, and visfatin levels significantly decreased after treatment of hyperthyroidism [115]. This higher concentration of visfatin may be related to visfatin resistance in hyperthyroidism. Experimental studies revealed controversial results indicating that T3 could accelerate adipocyte differentiation with increased visfatin levels [116], whereas MacLaren et al. have reported down regulation of visfatin mRNA expression by T3 in adipocytes [117]. Han et al. studied the regulation of visfatin by TH in-vivo (human and animal) and in-vitro models. Clinical subjects and animal models had elevated plasma visfatin concentrations in both hypo and hyperthyroid groups compared with controls. $\mathrm{T} 3$ induced a remarkable increase in visfatin mRNA expression 
in 3T3-L1 cells at low concentrations followed by a sharp decrease at higher concentrations [118]. Controversial results might be explained by differences in ethnic or methodological factors or heterogeneity of thyroid dysfunction [119]. The pro-inflammatory cytokine IL-6 has the ability to induce the expression of visfatin in vitro which is increased in patients with thyroid dysfunction [120-122]. Therefore, it is likely that visfatin release from adipose tissue may be affected directly or indirectly via proinflammatory cytokines implicating them in thyroid dysfunction [34].

\section{Vaspin}

VAT-derived serine protease inhibitor (Vaspin) is an insulinsensitizing adipocytokine $[123,124]$. Vaspin's single-nucleotide polymorphic (SNP) form rs2236242 has been reported to have increased risk of diabetes independent of obesity, suggesting a link between vaspin and glucose metabolism [125]. Youn et al. reported increased vaspin levels in obese and insulin resistant subjects [126]. El-Mesallamy et al. found higher vaspin concentrations in both obese and non-obese T2DM patients than in controls, whereas Gulcelik et al. reported that diabetic women with good glycemic control had lower vaspin levels than those with poor glycemic control $[127,128]$. Some studies suggested that vaspin gene expression in human adipose tissue and circulating vaspin levels were positively associated with obesity-associated diseases and T2DM [129-132]. Furthermore, it is indicated that vaspin plays an important function in adipoinsular axis, and may be associated with insulin resistance in obese subjects, including patients with T2DM [129]. On the basis of research studies it was hypothesized that vaspin may be involved in the glucose metabolism and the development of T2DM in human. Vaspin has been reported to improve glucose tolerance and insulin sensitivity in murine one side on the contrary other side the conflicting results was reported to be positively associated with metabolic syndromes in human [130]. Hida et al. demonstrated that vaspin was barely detectable in OLETF (Otsuka Long-Evans Tokushima Fatty) rat at 6 weeks and was highly expressed in adipocytes of visceral white adipose tissues at 30 weeks, the age when obesity, body weight, and insulin levels peak in OLETF rats. The tissue expression of vaspin and its serum levels decreased with worsening of diabetes and body weight loss at 50 weeks [123]. Aforesaid observations were suggestive of increased serum vaspin with the progression of diabetes. Vaspin may increase at the beginning and decrease with worsening of diabetes in human [133]. Vaspin may have a compensatory role in insulin resistance in human obesity associated diseases. Hypothetically, just like adiponectin, low vaspin level might be concomitant with poor glycemic control in diabetic patients because of its impact on insulin sensitivity and glucose metabolism [124].

Only few research available which correlates the regulation of vaspin by TH. Gonzalez et al. observed that vaspin mRNA levels are significantly decreased in hyperthyroid rats and significantly increased in hypothyroid rats compared with the euthyroids without any changes in glucose and insulin levels, suggesting that thyroid dysfunction may affect vaspin expression [134]. Handisurya et al. examined the relationship between TSH, vaspin, and leptin levels before and after weight loss by bariatric surgery. A significant decrease in TSH levels in positive correlation with changes in serum vaspin levels were observed but were no definite conclusion stated, if vaspin causes the weight-loss-associated decrease of TSH levels, or changes in thyroid function or gastrointestinal peptides influenced serum vaspin levels [135]. Cinar et al. reported that vaspin levels were similar in euthyroid and hypothyroid subjects (subclinical and clinical hypothyroid), and no significant difference was observed in vaspin levels after normalization of TH. Moreover, vaspin levels were not correlated with TSH. Aforesaid data indicate that $\mathrm{TH}$ status has no influence on serum vaspin levels in humans $[34,136]$.

\section{Obestatin}

Obestatin, derived from preproghrelin which adopted an $\alpha$-helical secondary structure and seems to be required for binding of obestatin to its receptor $[137,138]$. Agnew et al. suggested that obestatin may signal via an adenylate cyclaselinked G protein-coupled receptors in the cardiovascular system, although the precise identity of the cognate receptor(s) for obestatin remains to be determined $[139,140]$. Obestatin has a short biological half-life but it is proposed to exert wideranging functions including, food intake, body weight, adiposity and fasting glucose/insulin. Whilst the precise nature of many of its effects is unclear but accumulating evidence supports positive actions on both metabolism and cardiovascular function $[141,142]$. Obestatin was first reported to inhibit jejunal contraction, food intake and body weight gain in rats, in addition to antagonizing ghrelin-induced contraction of isolated jejunum muscle, which is relevant to T2DM [137]. Some studies reported that the obestatin reduced antral and duodenal motility in the fed state while increased restoration of normal fasted-state duodenal activity $[143,144]$. Further, Saliakelis et al. observed the increased pre-prandial obestatin levels in children with unexplained delayed gastric emptying [145].

Obestatin and ghrelin both were reported to be secreted by human pancreatic islets and pancreatic beta cell lines, suggesting a synergistic relationship that may be connected with pancreatic beta cell function, enhance their viability and inhibit apoptosis [146-148]. Survival of beta cells was compromised upon incubation with an anti-obestatin antibody, whilst genes associated with insulin production, beta cell survival, growth and differentiation were up-regulated by obestatin, together with activation of Phosphoinositide 3-kinase (PI3K)/Protein kinase-B (PKB), ERK1/2 and cAMP [146].

Several groups have also demonstrated obestatin secretion from rat WAT and adipocytes from both mice and humans $[149,150]$. Decreased circulating obestatin has been documented in overweight/obese patients and those with impaired glucose 


\section{Journal of Endocrinology and Thyroid Research}

control, metabolic syndrome, T2DM and insulin resistance [151-155]. Inverse correlations between circulating obestatin and body mass index, insulin, glucose, leptin, HOMA-IR and glycosylated hemoglobin (HbA1c) have been reported [153-155]. Obestatin levels increased with body weight reduction following gastric banding and sleeve gastrectomy surgery in obese and T2DM patients, respectively, and with standard weight loss in obese children [156,157]. Although the majority of studies appear to support an inverse relationship between circulating obestatin and obesity/diabetes, increased obestatin levels have also been reported in patients with obesity, metabolic syndrome, impaired glucose control, T1DM [157-160]. Other studies have found obestatin levels to be unaltered following gastric surgery-induced weight loss in both obese and T2DM patients $[156,161,162]$.

Only few studies available which correlate the TD with obestatin levels and the results are inconsistent. Emami et al. reported decreased levels of obestatin in hypothyroidism and increased in hyperthyroidism [163]. Whilst, Kosowicz et al. demonstrated that hypothyroidism was associated with increased levels of obestatin and hyperthyroidism was associated with decreased levels of obestatin [164]. Gurgul et al. found a positive association between TSH levels, ghrelin, and obestatin in hypothyroidism and suggested that obestatin may be a modulatory molecule [165].

\section{Conclusion}

TD and DM are closely linked with each other and characterized by a complex interaction. IR states may increase thyroid gland nodularity. Changes in adipokine secretion due to thyroid dysfunction or DM may represent adaptive mechanisms to decrease or increase in basal energy expenditure and energy substrate requirements. Cytokine network imbalances may be involved in the interactions between TH, Insulin secretion and IR. Additional studies, particularly studying the interactions among the novel genes in the adipose tissue, adipocytokines, TH, Insulin and IR will generate further insights into the endocrine function of adipose tissue towards the progression of TD and DM.

\section{Disclosure Statement}

The authors have no conflicts of interest to disclose.

\section{References}

1. Mishra M, Sotto MR, Panta R, Miyares M, Solanki R (2017) Association of Diabetes mellitus and Thyroid disorders: A metabolic prospective. Asian Pac J health Sci 4(3): 253-262.

2. Chaker L, Ligthart S, Korevaar TI, Hofman A, Franco OH, et al. (2016) Thyroid function and risk of type 2 diabetes: a population-based prospective cohort study. BMC Med 14(1): 150.

3. Canaris GJ, Manowitz NR, Mayor G, Ridgway EC (2000) The Colorado thyroid disease prevalence study. Arch Intern Med 160(4): 526-534.

4. Gray RS, Irvine WJ, Clarke BF (1979) Screening for thyroid dysfunction in diabetics. Br Med J 2(6202): 1439.

5. Hage M, Zantout MS, Azar ST (2011) Thyroid disorders and diabetes mellitus. J Thyroid Res 2011: 439463.
6. Wang C (2013) The relationship between Type 2 Diabetes mellitus and related thyroid diseases. J Diabetes Res 2013: 390534

7. Brenta G, Danzi S, Klein I (2007) Potential therapeutic applications of thyroid hormone analogs. Nat Clin Pract Endocrinol Metab 3(9): 632640.

8. Lanni A, Moreno M, Goglia F (2016) Mitochondrial actions of Thyroid hormone. Compr Physiol 6(4): 1591-1607.

9. Shun CB, Donaghue KC, Phelan H, Twigg SM, Craig ME (2014) Thyroid autoimmunity in Type 1 diabetes: systematic review and meta-analysis. Diabet Med 31(2): 126-135.

10. Crunkhorn S, Patti ME (2008) Links between thyroid hormone action oxidative metabolism, and diabetes risk? Thyroid 18(2): 227-237.

11. Saunders J, Hall SE, Sönksen PH (1978) Thyroid hormones in insulin requiring diabetes before and after treatment. Diabetologia 15(1): 2932.

12. Yasar HY, Ertugrul O, Ertugrul B, Ertugrul D, Sahin M (2011) Insulin resistance in nodular thyroid disease. Endocr Res 36(4): 167-174.

13. Anil C, Akkurt A, Ayturk S, Kut A, Gursoy A (2013) Impaired glucose metabolism is a risk factor for increased thyroid volume and nodule prevalence in a mild-to-moderate iodine deficient area. Metabolism 62(7): 970-975.

14. Rezzónico J, Rezzónico M, Pusiol E, Pitoia F, Niepomniszcze H (2011) Metformin treatment for small benign thyroid nodules in patients with insulin resistance. Metab Syndr Relat Disord 9(1): 69-75.

15. World Health Organization (2016) Global report on diabetes. WHO, Geneva, Switzerland

16. Roglic G (2016) WHO Global report on diabetes: A summary. Int J Non-Commun Dis 1(1): 3-8.

17. Centers for Disease Control and Prevention. National Diabetes Statistics Report (2017) Centers for Disease Control and Prevention, U.S. Department of Health and Human Services, Atlanta, Georgia, USA.

18. Statistics About Diabetes (2017) American Diabetes Association.

19. Wang C, Crapo LM (1997) The epidemiology of thyroid disease and implications for screening. Endocrinol Metab Clin North Am 26(1): 189218.

20. Tunbridge WM, Evered DC, Hall R, Appleton D, Brewis M, et al. (1977) The spectrum of thyroid disease in a community: the Whickham survey. Clin Endocrinol (Oxf) 7(6): 481-493.

21. Hollowell JG, Staehling NW, Flanders WD, Hannon WH, Gunter EW, et al. (2002) Serum TSH, T4, and thyroid antibodies in the United States population (1988 to 1994): National Health and Nutrition Examination Survey (NHANES III). J Clin Endocrinol Metab 87(2): 489-499.

22. Sawin CT, Castelli WP, Hershman JM, McNamara P, Bacharach P (1985) The aging thyroid. Thyroid deficiency in the Framingham study. Arch Intern Med 145(8): 1386-1388.

23. Perros P, McCrimmon RJ, Shaw G, Frier BM (1995) Frequency of thyroid dysfunction in diabetic patients: value of annual screening. Diabet Med 12(7): 622-627.

24. Reiners C, Wegscheider K, Schicha H, Theissen P, Vaupel R, et al. (2004) Prevalence of thyroid disorders in the working population of Germany: ultrasonography screening in 96,278 unselected employees. Thyroid 14(11): 926-932.

25. Papazafiropoulou A, Sotiropoulos A, Kokolaki A, Kardara M, Stamataki P (2010) Prevalence of thyroid dysfunction among Greek Type 2 diabetic patients attending an outpatient clinic. J Clin Med Res 2(2): 75-78.

26. Radaideh AR, Nusier MK, Amari FL, Bateiha AE, El-Khateeb MS, et al. (2004) Thyroid dysfunction in patients with type 2 diabetes mellitus in Jordan. Saudi Med J 25(8): 1046-1050. 


\section{Journal of Endocrinology and Thyroid Research}

27. Han C, He X, Xia X, Li Y, Shi X, et al. (2015) Subclinical hypothyroidism and type 2 diabetes: A systematic review and meta-analysis. PLoS One 10(8): e0135233.

28. Rivolta G, Cerutti R, Colombo R, Miano G, Dionisio P, et al. (1999) Prevalence of subclinical hypothyroidism in a population living in the Milan metropolitan area. J Endocrinol Invest 22(9): 693-697.

29. Meng F, Zhao R, Liu P, Liu L, Liu S (2013) Assessment of iodine status in children, adults, pregnant women and lactating women in iodine-replete areas of China. PLoS One 8(11): e81294.

30. Nakamura K, Fuster JJ, Walsh K (2014) Adipokines: a link between obesity and cardiovascular disease. J Cardiol 63(4): 250-259.

31. Cao H (2014) Adipocytokines in obesity and metabolic disease. J Endocrinol 220(2): T47-T59.

32. Kim KJ, Kim BY, Mok JO, Kim CH, Kang SK, et al. (2015) Serum concentrations of ghrelin and leptin according to thyroid hormone condition, and their correlations with insulin resistance. Endocrinol Metab (Seoul) 30(3): 318-325.

33. Kar K, Sinha S (2017) Variations of adipokines and insulin resistance in primary hypothyroidism. J Clin Diagn Res 11(8): BC07-BC09.

34. Cinar N, Gurlek A (2013) Association between novel adipocytokines adiponectin, vaspin, visfatin, and thyroid: An experimental and clinical update. Endocr Connect 2(4): R30-R38.

35. Yamauchi T, Kamon J, Ito Y, Tsuchida A, Yokomizo T, et al. (2003) Cloning of adiponectin receptors that mediate antidiabetic metabolic effects. Nature 423(6941): 762-769.

36. Berg AH, Combs TP, Scherer PE (2002) ACRP30/adiponectin: An adipokine regulating glucose and lipid metabolism. Trends Endocrinol Metab 13(2): 84-89.

37. Tsuchida A, Yamauchi T, Takekawa S, Hada Y, Ito Y, et al. (2005) Peroxisome proliferator-activated receptor (PPAR) $\alpha$ activation increases adiponectin receptors and reduces obesity-related inflammation in adipose tissue: comparison of activation of PPAR $\alpha$, PPAR $\gamma$, and their combination. Diabetes 54(12): 3358-3370.

38. Yadav A, Kataria MA, Saini V, Yadav A (2013) Role of leptin and adiponectin in insulin resistance. Clin Chim Acta 417: 80-84.

39. Chandran M, Phillips SA, Ciaraldi T, Henry RR (2003) Adiponectin: more than just another fat cell hormone? Diabetes Care 26(8): 24422450 .

40. Diez JJ, Iglesias P (2003) The role of the novel adipocyte-derived hormone adiponectin in human disease. Eur J Endocrinol 148(3): 293-300.

41. Arita Y, Kihara S, Ouchi N, Takahashi M, Maeda K, et al. (2012) Paradoxical decrease of an adipose-specific protein, adiponectin, in obesity. Biochem Biophys Res Commun 257(1): 79-83.

42. Bastard JP, Maachi M, Lagathu C, Kim MJ, Caron M, et al. (2006) Recent advances in the relationship between obesity, inflammation, and insulin resistance. Eur Cytokine Netw 17(1): 4-12.

43. Fernández-Real JM, López-Bermejo A, Casamitjana R, Ricart W (2003) Novel interactions of adiponectin with the endocrine system and inflammatory parameters. J Clin Endocrinol Metab 88(6): 2714-2718.

44. Ahima RS, Qi Y, Singhal NS, Jackson MB, Scherer PE (2006) Brain adipocytokine action and metabolic regulation. Diabetes 55(Suppl 1): S145-s154.

45. Aydogan Bİ, Sahin M (2013) Adipocytokines in thyroid dysfunction. ISRN Inflamm 2013: 646271.

46. Kokkinos A, Mourouzis I, Kyriaki D, Pantos C, Katsilambros N, et al. (2007) Possible implications of leptin, adiponectin and ghrelin in the regulation of energy homeostasis by thyroid hormone. Endocrine $32(1): 30-32$
47. Aragão CN, Souza LL, Cabanelas A, Oliveira KJ, Pazos-Moura CC (2007) Effect of experimental hypo- and hyperthyroidism on serum adiponectin. Metabolism 56(1): 6-11

48. Barington M, Brorson MM, Hofman-Bang J, Rasmussen ÅK, Holst B, et al. (2017) Ghrelin-mediated inhibition of the TSH-stimulated function of differentiated human thyrocytes ex vivo. PLoS One 12(9): e0184992.

49. Seifi S, Tabandeh MR, Nazifi S, Saeb M, Shirian S, Sarkoohi P (2012) Regulation of adiponectin gene expression in adipose tissue by thyroid hormones. J Physiol Biochem 68(2): 193-203.

50. Cabanelas A, Cordeiro A, Santos Almeida NA, Monteiro de Paula GS, Coelho VM, et al. (2010) Effect of triiodothyronine on adiponectin expression and leptin release by white adipose tissue of normal rats. Horm Metab Res 42(4): 254-260.

51. Fujimoto N, Matsuo N, Sumiyoshi H, Yamaguchi K, Saikawa T, et al. (2005) Adiponectin is expressed in the brown adipose tissue and surrounding immature tissues in mouse embryos. Biochim Biophys Acta 1731(1): 1-12.

52. Dimitriadis G, Mitrou P, Lambadiari V, Boutati E, Maratou E, et al (2006) Insulin action in adipose tissue and muscle in hypothyroidism. J Clin Endocrinol Metab 91(12): 4930-4937.

53. Nagasaki T, Inaba M, Hiura Y, Tahara H, Kumeda Y, et al. (2005) Plasma levels of adiponectin and soluble thrombomodulin in hypothyroid patients with normal thyroid function following levothyroxine replacement therapy. Biomed Pharmacother 59(10): 571-577.

54. Yaturu S, Prado S, Grimes SR (2004) Changes in adipocyte hormones leptin, resistin, and adiponectin in thyroid dysfunction. J Cell Biochem 93(3): 491-496.

55. Saito T, Kawano T, Saito T, Ikoma A, Namai K, et al. (2005) Elevation of serum adiponectin levels in Basedow disease. Metabolism 54(11): $1461-1466$.

56. Santini F, Marsili A, Mammoli C, Valeriano R, Scartabelli G, et al. (2004) Serum concentrations of adiponectin and leptin in patients with thyroid dysfunctions. J Endocrinol Invest 27(2): RC5-RC7.

57. Iglesias P, Alvarez Fidalgo P, Codoceo R, Díez JJ (2003) Serum concentrations of adipocytokines in patients with hyperthyroidism and hypothyroidism before and after control of thyroid function. Clin Endocrinol (Oxf) 59(5): 621-629.

58. Altinova AE, Törüner FB, Aktürk M, Bukan N, Cakir N, et al. (2006) Adiponectin levels and cardiovascular risk factors in hypothyroidism and hyperthyroidism. Clin Endocrinol (Oxf) 65(4): 530-535.

59. Seifi S, Nazifi S, Tabandeh MR, Saeb M (2013) AdipoR1 and AdipoR2 gene expression are regulated by thyroid hormones in adipose tissue. Mol Cell Biochem 377(1-2): 55-63.

60. Schultz M, Kistorp C, Raymond I, Dimsits J, Tuxen C, et al. (2011) Cardiovascular events in thyroid disease: a population based, prospective study. Horm Metab Res 43(9): 653-659.

61. Jung CH, Kim BY, Mok JO, Kang SK, Kim CH (2014) Association between serum adipocytokine levels and microangiopathies in patients with type 2 diabetes mellitus. J Diabetes Investig 5(3): 333-339.

62. Ahima RS, Antwi DA (2008) Brain regulation of appetite and satiety. Endocrinol Metab Clin North Am 37(4): 811-823.

63. Zuo H, Shi Z, Yuan B, Dai Y, Wu G, et al. (2013) Association between serum leptin concentrations and insulin resistance: a population-based study from China. PLoS One 8(1): e54615.

64. Mantzoros CS, Magkos F, Brinkoetter M, Sienkiewicz E, Dardeno TA, et al. (2011) Leptin in human physiology and pathophysiology. Am J Physiol Endocrinol Metab 301(4): E567-E584.

65. Mazaki-Tovi M, Feuermann Y, Segev G, Klement E, Yas-Natan E, et al (2010) Increased serum leptin and insulin concentrations in canine hypothyroidism. Vet J 183(1): 109-114. 
66. Kautzky-Willer A, Ludwig C, Nowotny P, Roden A, Huemer C, et al (1999) Elevation of plasma leptin concentrations in obese hyperinsulinaemic hypothyroidism before and after treatment. Eur J Clin Invest 29(5): 395-403.

67. Oge A, Bayraktar F, Saygili F, Guney E, Demir S (2005) TSH influences serum leptin levels independent of thyroid hormones in hypothyroid and hyperthyroid patients. Endocr J 52(2): 213-217.

68. Kaplan O, Uzum AK, Aral H, Uzum G, Tunali V, et al. (2012) Unchanged serum adipokine concentrations in the setting of short-term thyroidectomy-induced hypothyroidism. Endocr Pract 18(6): 887-893.

69. Shahramian I, Noori N, Ramezani A, Sharafi E, Akhlaghi E (2013) Correlation between serum leptin level and thyroid hormones in children with major beta-thalassemia. Iran J Ped Hematol Oncol 3(4): 149-153.

70. Sesmilo G, Casamitjana R, Halperin I, Gomis R, Vilardell E (1998) Role of thyroid hormones on serum leptin levels. Eur J Endocrinol 139(4): 428-430.

71. Macek Jílková Z, Pavelka S, Flachs P, Hensler M, Kůs V, et al. (2010) Modulation of type I iodothyronine 5'-deiodinase activity in white adipose tissue by nutrition: possible involvement of leptin. Physiol Res 59(4): 561-569.

72. Menendez C, Baldelli R, Camiña JP, Escudero B, Peino R, et al. (2003) TSH stimulates leptin secretion by a direct effect on adipocytes. J Endocrinol 176(1): 7-12.

73. Braclik M, Marcisz C, Giebel S, Orzel A (2008) Serum leptin and ghrelin levels in premenopausal women with stable body mass index during treatment of thyroid dysfunction. Thyroid 18(5): 545-550.

74. Korbonits M, Goldstone AP, Gueorguiev M, Grossman AB (2004) Ghrelin: a hormone with multiple functions. Front Neuroendocrinol 25(1): 27-68.

75. Mihalache L, Gherasim A, Niță O, Ungureanu MC, Pădureanu SS, et al (2016) Effects of ghrelin in energy balance and body weight homeostasis. Hormones (Athens) 15(2): 186-196.

76. Cummings DE, Shannon MH (2003) Roles for ghrelin in the regulation of appetite and body weight. Arch Surg 138(4): 389-396.

77. Flanagan DE, Evans ML, Monsod TP, Rife F, Heptulla RA, et al. (2003) The influence of insulin on circulating ghrelin. Am J Physiol Endocrinol Metab 284(2): E313-E316.

78. Chen Y, Wu X, Wu R, Sun X, Yang B, et al. (2016) Changes in profile of lipids and adipokines in patients with newly diagnosed hypothyroidism and hyperthyroidism. Sci Rep 6: 26174

79. El Gawad SS, El Kenawy F, Mousa AA, Omar AA (2012) Plasma levels of resistin and ghrelin before and after treatment in patients with hyperthyroidism. Endocr Pract 18(3): 376-381.

80. Chubb SA, Davis WA, Davis TM (2005) Interactions among thyroid function, insulin sensitivity, and serum lipid concentrations: the Fremantle diabetes study. J Clin Endocrinol Metab 90(9): 5317-5320.

81. Riis AL, Hansen TK, Moller N, Weeke J, Jorgensen JO (2003) Hyperthyroidism is associated with suppressed circulating ghrelin levels. J Clin Endocrinol Metab 88(2): 853-857.

82. Broglio F, Arvat E, Benso A, Gottero C, Muccioli G, et al. (2001) Ghrelin, a natural GH secretagogue produced by the stomach, induces hyperglycemia and reduces insulin secretion in humans. J Clin Endocrinol Metab 86(10): 5083-5086.

83. Tong J, Prigeon RL, Davis HW, Bidlingmaier M, Kahn SE, et al. (2010) Ghrelin suppresses glucose-stimulated insulin secretion and deteriorates glucose tolerance in healthy humans. Diabetes 59(9): 2145-2151.

84. Amini P, Wadden D, Cahill F, Randell E, Vasdev S, et al. (2012) Serum acylated ghrelin is negatively correlated with the insulin resistance in the CODING study. PLoS One 7(9): e45657.
85. Gjedde S, Vestergaard ET, Gormsen LC, Riis AL, Rungby J, et al. (2008) Serum ghrelin levels are increased in hypothyroid patients and become normalized by L-thyroxine treatment. J Clin Endocrinol Metab 93(6): 2277-2280.

86. Caminos JE, Seoane LM, Tovar SA, Casanueva FF, Dieguez C (2002) Influence of thyroid status and growth hormone deficiency on ghrelin. Eur J Endocrinol 147(1): 159-163.

87. Sadegholvad A, Afkhamizadeh M, Ranjbar-Omrani G (2007) Serum ghrelin changes in thyroid dysfunction. Arch Iran Med 10(2): 168-170.

88. Tanda ML, Lombardi V, Genovesi M, Ultimieri F, Lai A, et al. (2009) Plasma total and acylated Ghrelin concentrations in patients with clinical and subclinical thyroid dysfunction. J Endocrinol Invest 32(1): 74-78.

89. Steppan CM, Bailey ST, Bhat S, Brown EJ, Banerjee RR, et al. (2001) The hormone resistin links obesity to diabetes. Nature 409(6818): 307 312.

90. Patel L, Buckels AC, Kinghorn IJ, Murdock PR, Holbrook JD, et al. (2003) Resistin is expressed in human macrophages and directly regulated by PPAR gamma activators. Biochem Biophys Res Commun 300(2): 472476.

91. Azab N, Abdel-Aziz T, Ahmed A, El-deen IM (2016) Correlation of serum resistin level with insulin resistance and severity of retinopathy in type 2 diabetes mellitus. J Saudi Chem Soc 20(3): 272-277.

92. Al-Harithy RN, Al-Ghamdi S (2005) Serum resistin, adiposity and insulin resistance in Saudi women with type 2 diabetes mellitus. Ann Saudi Med 25(4): 283-287.

93. Fujinami A, Obayashi H, Ohta K, Ichimura T, Nishimura M, et al. (2004) Enzyme-linked immunosorbent assay for circulating human resistin: resistin concentrations in normal subjects and patients with type 2 diabetes. Clin Chim Acta 339(1-2): 57-63.

94. Heilbronn LK, Rood J, Janderova L, Albu JB, Kelley DE, et al. (2004) Relationship between serum resistin concentrations and insulin resistance in nonobese, obese, and obese diabetic subjects. J Clin Endocrinol Metab 89(4): 1844-1848.

95. Takeishi Y, Niizeki T, Arimoto T, Nozaki N, Hirono O, et al. (2007) Serum resistin is associated with high risk in patients with congestive heart failure-a novel link between metabolic signals and heart failure. Circ J 71(4): 460-464.

96. Ziora KT, Oswiecimska JM, Swietochowska E, Ostrowska Z, Stojewska M, et al. (2011) Assessment of serum levels resistin in girls with anorexia nervosa. Part II. Relationships between serum levels of resistin and thyroid, adrenal and gonadal hormones. Neuro Endocrinol Lett 32(5): 697-703.

97. Saddi-Rosa P, Oliveira CS, Giuffrida FM, Reis AF (2010) Visfatin, glucose metabolism and vascular disease: a review of evidence. Diabetol Metab Syndr 2: 21.

98. Costford SR, Bajpeyi S, Pasarica M, Albarado DC, Thomas SC, et al. (2010) Skeletal muscle NAMPT is induced by exercise in humans. Am J Physiol Endocrinol Metab 298(1): E117-E126.

99. Curat CA, Wegner V, Sengenès C, Miranville A, Tonus C, et al. (2006) Macrophages in human visceral adipose tissue: increased accumulation in obesity and a source of resistin and visfatin. Diabetologia 49(4): 744-747.

100. Varma V, Yao-Borengasser A, Rasouli N, Bodles AM, Phanavanh B, et al. (2007) Human visfatin expression: relationship to insulin sensitivity, intramyocellular lipids, and inflammation. J Clin Endocrinol Metab 92(2): 666-672.

101. Romacho T, Sánchez-Ferrer CF, Peiró C (2013) Visfatin/Nampt: an adipokine with cardiovascular impact. Mediators Inflamm 2013: 946427.

102. Laudes M, Oberhauser F, Schulte DM, Freude S, Bilkovski R, et al. (2010) Visfatin/PBEF/Nampt and resistin expressions in circulating 
blood monocytes are differentially related to obesity and type 2 diabetes in humans. Horm Metab Res 42(4): 268-273.

103. Nourbakhsh M, Nourbakhsh M, Gholinejad Z, Razzaghy-Azar M (2015) Visfatin in obese children and adolescents and its association with insulin resistance and metabolic syndrome. Scand J Clin Lab Invest 75(2): 183-188.

104. Kocełak P, Olszanecka-Glinianowicz M, Owczarek AJ, Krupa W, Obirek P, et al. (2015) Plasma visfatin/nicotinamide phosphoribosyltransferase (visfatin/NAMPT) concentration in elderly subjects with metabolic syndrome. Pol Arch Med Wewn 125(6): 402-413.

105. Sommer G, Garten A, Petzold S, Beck-Sickinger AG, Blüher M, et al. (2008) Visfatin/PBEF/Nampt: structure, regulation and potential function of a novel adipokine. Clin Sci (Lond) 115(1): 13-23.

106. Haider DG, Schindler K, Schaller G, Prager G, Wolzt M, et al. (2006) Increased plasma visfatin concentrations in morbidly obese subjects are reduced after gastric banding. J Clin Endocrinol Metab 91(4): 1578-1581.

107. Skop V, Kontrová K, Zídek V, Pravenec M, Kazdová L, et al. (2010) Autocrine effects of visfatin on hepatocyte sensitivity to insulin action. Physiol Res 59(4): 615-618.

108. Beltowski J (2006) Apelin and visfatin: unique "beneficial" adipokines upregulated in obesity? Med Sci Monit 12(6): RA112-RA119.

109. Revollo JR, Körner A, Mills KF, Satoh A, Wang T, et al. (2007) Nampt/ PBEF/Visfatin regulates insulin secretion in beta cells as a systemic NAD biosynthetic enzyme. Cell Metab 6(5): 363-375.

110. Lopez-Bermejo A, Chico-Julia B, Fernandez-Balsells M, Recasens M, Esteve E, et al. (2006) Serum visfatin increases with progressive betacell deterioration. Diabetes 55(10): 2871-2875.

111. Haider DG, Schaller G, Kapiotis S, Maier C, Luger A, et al. (2006) The release of the adipocytokine visfatin is regulated by glucose and insulin. Diabetologia 49(8): 1909-1914.

112. Brown JE, Onyango DJ, Ramanjaneya M, Conner AC, Patel ST, et al (2010) Visfatin regulates insulin secretion, insulin receptor signalling and mRNA expression of diabetes-related genes in mouse pancreatic beta-cells. J Mol Endocrinol 44(3): 171-178.

113. Chen MP, Chung FM, Chang DM, Tsai JC, Huang HF, et al. (2006) Elevated plasma level of visfatin/pre-B cell colony-enhancing factor in patients with type 2 diabetes mellitus. J Clin Endocrinol Metab 91(1): 295-299.

114. Dogru T, Sonmez A, Tasci I, Bozoglu E, Yilmaz MI, et al. (2007) Plasma visfatin levels in patients with newly diagnosed and untreated type 2 diabetes mellitus and impaired glucose tolerance. Diabetes Res Clin Pract 76(1): 24-29.

115. Chu CH, Lee JK, Wang MC, Lu CC, Sun CC, et al. (2008) Change of visfatin, C-reactive protein concentrations, and insulin sensitivity in patients with hyperthyroidism. Metabolism 57(10): 1380-1383.

116. Tanaka M, Nozaki M, Fukuhara A, Segawa K, Aoki N, et al. (2007) Visfatin is released from 3T3-L1 adipocytes via a non-classical pathway. Biochem Biophys Res Commun 359(2): 194-201.

117. MacLaren R, Cui W, Cianflone K (2007) Visfatin expression is hormonally regulated by metabolic and sex hormones in 3T3-L1 preadipocytes and adipocytes. Diabetes Obes Metab 9(4): 490-497.

118. Han J, Zhang TO, Xiao WH, Chang CQ, Ai H (2012) Up-regulation of visfatin expression in subjects with hyperthyroidism and hypothyroidism is partially relevant to a nonlinear regulation mechanism between visfatin and tri-iodothyronine with various concentrations. Chin Med J (Engl) 125(5): 874-881.

119. Moschen AR, Kaser A, Enrich B, Mosheimer B, Theurl M, et al. (2007) Visfatin, an adipocytokine with proinflammatory and immunomodulating properties. J Immunol 178(3): 1748-1758.
120. Celik I, Akalin S, Erbas T (1995) Serum levels of interleukin 6 and tumor necrosis factor-alpha in hyperthyroid patients before and after propylthiouracil treatment. Eur J Endocrinol 132(6): 668-672.

121. Salvi M, Pedrazzoni M, Girasole G, Giuliani N, Minelli R, et al. (2000) Serum concentrations of proinflammatory cytokines in Graves' disease: effect of treatment, thyroid function, ophthalmopathy and cigarette smoking. Eur J Endocrinol 143(2): 197-202.

122. Ognjanovic S, Bao S, Yamamoto SY, Garibay-Tupas J, Samal B, et al. (2001) Genomic organization of the gene coding for human pre-B-cell colony enhancing factor and expression in human fetal membranes. J Mol Endocrinol 26(2): 107-117.

123. Hida K, Wada J, Eguchi J, Zhang H, Baba M, et al. (2005) Visceral adipose tissue-derived serine protease inhibitor: a unique insulinsensitizing adipocytokine in obesity. Proc Natl Acad Sci USA 102(3D): 10610-10615.

124. Jian W, Peng W, Xiao S, Li H, Jin J, et al. (2014) Role of serum vaspin in progression of type 2 diabetes: a 2-year cohort study. PLoS One 9(4): e94763.

125. Kempf K, Rose B, Illig T, Rathmann W, Strassburger K, et al. (2010) Vaspin (SERPINA12) genotypes and risk of type 2 diabetes: results from the MONICA/KORA studies. Exp Clin Endocrinol Diabetes 118(3): 184-189.

126. Youn BS, Klöting N, Kratzsch J, Lee N, Park JW, et al. (2008) Serum vaspin concentrations in human obesity and type 2 diabetes. Diabetes 57(2): 372-377.

127. El-Mesallamy HO, Kassem DH, El-Demerdash E, Amin AI (2011) Vaspin and visfatin/Nampt are interesting interrelated adipokines playing a role in the pathogenesis of type 2 diabetes mellitus. Metabolism 60(1): 63-70.

128. Gulcelik NE, Karakaya J, Gedik A, Usman A, Gurlek A (2009) Serum vaspin levels in type 2 diabetic women in relation to microvascular complications. Eur J Endocrinol 160(1): 65-70.

129. Tan BK, Heutling D, Chen J, Farhatullah S, Adya R, et al. (2008) Metformin decreases the adipokine vaspin in overweight women with polycystic ovary syndrome concomitant with improvement in insulin sensitivity and a decrease in insulin resistance. Diabetes 57(6): 15011507.

130. Aktas B, Yilmaz Y, Eren F, Yonal O, Kurt R, et al. (2011) Serum levels of vaspin, obestatin, and apelin-36 in patients with nonalcoholic fatty liver disease. Metabolism 60(4): 544-549.

131. Cakal E, Ustun Y, Engin-Ustun Y, Ozkaya M, Kilinc M (2011) Serum vaspin and $\mathrm{C}$-reactive protein levels in women with polycystic ovaries and polycystic ovary syndrome. Gynecol Endocrinol 27(7): 491-495.

132. Choi SH, Wak SH, Lee Y, Moon MK, Lim S, et al. (2011) Plasma vaspin concentrations are elevated in metabolic syndrome in men and are correlated with coronary atherosclerosis in women. Clin Endocrinol (Oxf) 75(5): 628-635.

133. Aust G, Richter O, Rohm S, Kerner C, Hauss J, et al. (2009) Vaspin serum concentrations in patients with carotid stenosis. Atherosclerosis 204(1): 262-266.

134. Gonzalez CR, Caminos JE, Vázquez MJ, Garcés MF, Cepeda LA, et al. (2009) Regulation of visceral adipose tissue-derived serine protease inhibitor by nutritional status, metformin, gender and pituitary factors in rat white adipose tissue. J Physiol 587(Pt 14): 3741-3750.

135. Handisurya A, Riedl M, Vila G, Maier C, Clodi M, et al. (2010) Serum vaspin concentrations in relation to insulin sensitivity following RYGB-induced weight loss. Obes Surg 20(2): 198-203.

136. Cinar N, Gulcelik NE, Aydin K, Akin S, Usman A, et al. (2011) Serum vaspin levels in hypothyroid patients. Eur J Endocrinol 165(4): 563569. 
137. Zhang JV, Ren P, Avsian-Kretchmer O (2005) Obestatin, a peptide encoded by the ghrelin gene, opposes ghrelin's effects on food intake. Science 310(5750): 996-999.

138. Alen BO, Nieto L, Gurriaran-Rodriguez U, Mosteiro CS, Alvarez-Perez JC, et al. (2012) The NMR structure of human obestatin in membranelike environments: insights into the structure-bioactivity relationship of obestatin. PLoS One 7(10): e45434.

139. Agnew AJ, Robinson E, McVicar CM, Harvey AP, Ali IH, et al. (2012) The gastrointestinal peptide obestatin induces vascular relaxation via specific activation of endothelium-dependent NO signalling. Br J Pharmacol 166(1): 327-338.

140. Cowan E, Burch KJ, Green BD, Grieve DJ (2016) Obestatin as a key regulator of metabolism and cardiovascular function with emerging therapeutic potential for diabetes. Br J Pharmacol 173(14): 21652181.

141. Khirazova EE, Bayzhumanov AA, Motorykina ES, Devyatov AA Maslova MV, et al. (2015) Antioxidant defense system after single and chronic administration of obestatin and its fragment (1-4) to normal and overweight male rats. Bull Exp Biol Med 159(1): 38-40.

142. Motorykina ES, Khirazova EE, Maslova MV, Maklakova AS, Graf AV, et al. (2015) Changes in feeding and drinking motivations and glucose content in male rats after single or chronic administration of obestatin or its fragment (1-4). Dokl Biol Sci 460: 1-4.

143. Ataka K, Inui A, Asakawa A, Kato I, Fujimiya M (2008) Obestatin inhibits motor activity in the antrum and duodenum in the fed state of conscious rats. Am J Physiol Gastrointest Liver Physiol 294(5): G1210-G1218.

144. Fujimiya M, Ataka K, Asakawa A, Chen CY, Kato I, et al. (2012) Regulation of gastroduodenal motility: acyl ghrelin, des-acyl ghrelin and obestatin and hypothalamic peptides. Digestion 85(2): 90-94.

145. Saliakelis E, Iakovou I, Varlamis G, Karatzas N, Garstioni S, Fotoulaki M (2014) Serum obestatin, ghrelin, and ghrelin/obestatin ratio are increased in children with symptoms suggestive of delayed gastric emptying of unclear etiology. Eur J Nucl Med Mol Imaging 41: S579-S580.

146. Granata R, Settanni F, Gallo D, Trovato L, Biancone L, et al. (2008) Obestatin promotes survival of pancreatic beta-cells and human islets and induces expression of genes involved in the regulation of beta-cell mass and function. Diabetes 57(4): 967-979.

147. Granata R, Baragli A, Settanni F, Scarlatti F, Ghigo E (2010) Unraveling the role of the ghrelin gene peptides in the endocrine pancreas. J Mol Endocrinol 45(3): 107-118.

148. Favaro E, Granata R, Miceli I, Baragli A, Settanni F, et al. (2012) The ghrelin gene products and exendin-4 promote survival of human pancreatic islet endothelial cells in hyperglycaemic conditions, through phosphoinositide 3-kinase/Akt, extracellular signal-related kinase (ERK) 1/2 and cAMP/protein kinase A (PKA) signalling pathways. Diabetologia 55(4): 1058-1070.

149. Granata R, Gallo D, Luque RM, Baragli A, Scarlatti F, et al. (2012) Obestatin regulates adipocyte function and protects against dietinduced insulin resistance and inflammation. FASEB J 26(8): 33933411.

150. Gurriarán-Rodríguez U, Al-Massadi O, Roca-Rivada A, Crujeiras AB, Gallego R, et al. (2011) Obestatin as a regulator of adipocyte metabolism and adipogenesis. J Cell Mol Med 15(9): 1927-1940.

151. Gao XY, Kuang HY, Liu XM, Ma ZB (2010) Decreased gastric body mucosa obestatin expression in overweight and obese patients. Peptides 31(2): 291-296.
152. Cui AD, Gai NN, Zhang XH, Jia KZ, Yang YL, et al. (2012) Decreased serum obestatin consequent upon TRIB3 Q84R polymorphism exacerbates carotid atherosclerosis in subjects with metabolic syndrome. Diabetol Metab Syndr 4(1): 52.

153. Shen C, Yu T, Tang ZH, Wu KM (2013) Changes in ghrelin and obestatin levels before and after a meal in children with simple obesity and anorexia. Horm Res Paediatr 79(6): 341-346.

154. Gu PY, Kang DM, Wang WD, Chen Y, Zhao ZH, et al. (2013) Relevance of plasma obestatin and early arteriosclerosis in patients with type 2 diabetes mellitus. J Diabetes Res 2013: 563919.

155. Wang WM, Li SM, Du FM, Zhu ZC, Zhang JC, et al. (2014) Ghrelin and obestatin levels in hypertensive obese patients. J Int Med Res 42(6): 1202-1208.

156. Lee WJ, Chen CY, Ser KH, Chong K, Chen SC, et al. (2013) Differential influences of gastric bypass and sleeve gastrectomy on plasma nesfatin-1 and obestatin levels in patients with type 2 diabetes mellitus. Curr Pharm Des 19(32): 5830-5835.

157. Arrigo T, Gitto E, Ferraù V, Munafò C, Alibrandi A, et al. (2012) Effect of weight reduction on leptin, total ghrelin and obestatin concentrations in prepubertal children. J Biol Regul Homeost Agents 26 (1 Suppl): S95-S103.

158. Sedlackova D, Kopeckova J, Papezova H, Hainer V, Kvasnickova H, et al. (2012) Comparison of a high-carbohydrate and high protein breakfast effect on plasma ghrelin, obestatin, NPY and PYY levels in women with anorexia and bulimia nervosa. Nutr Metab (Lond) 9(1): 52.

159. Mora M, Granada ML, Roca M, Palomera E, Puig R, et al. (2013) Obestatin does not modify weight and nutritional behavior but is associated with metabolic syndrome in old women. Clin Endocrinol (Oxf) 78: 882-890.

160. Prodam F, Cadario F, Bellone S, Trovato L, Moia S, et al. (2014) Obestatin levels are associated with C-peptide and anti-insulin antibodies at the onset whereas unacylated and acylated ghrelin levels are not predictive of long-term metabolic control in children with type 1 diabetes. J Clin Endocrinol Metab 99(4): E599-E607.

161. Roth C, Reinehr T, Schernthaner G, Kopp H, Kriwanek S, et al. (2009) Ghrelin and obestatin levels in severely obese women before and after weight loss after Roux-en-Y gastric bypass surgery. Obes Surg 19(1): 29-35.

162. Siejka A, Jankiewicz-Wika J, Kołomecki K, Cywiński J, Piestrzeniewicz $\mathrm{K}$, et al. (2013) Long-term impact of vertical banded gastroplasty (VBG) on plasma concentration of leptin, soluble leptin receptor, ghrelin, omentin-1, obestatin, and retinol binding protein 4 (RBP4) in patients with severe obesity. Cytokine 64(2): 490-493.

163. Emami A, Nazem R, Hedayati M (2014) Is association between thyroid hormones and gut peptides, ghrelin and obestatin, able to suggest new regulatory relation between the HPT axis and gut? Regul Pept 189: 17-21.

164. Kosowicz J, Baumann-Antczak A, Ruchała M, Gryczyñska M, Gurgul E, et al. (2011) Thyroid hormones affect plasma ghrelin and obestatin levels. Horm Metab Res 43(2): 121-125.

165. Gurgul E, Ruchala M, Kosowicz J, Zamyslowska H, Wrotkowska E, et al. (2012) Ghrelin and obestatin in thyroid dysfunction. Endokrynol Pol 63(6): 456-462. 
(C) (i) This work is licensed under Creative Commons Attribution 4.0 Licens

DOI: 10.19080/JETR.2018.03.555612
Your next submission with Juniper Publishers will reach you the below assets

- Quality Editorial service

- Swift Peer Review

- Reprints availability

- E-prints Service

- Manuscript Podcast for convenient understanding

- Global attainment for your research

- Manuscript accessibility in different formats ( Pdf, E-pub, Full Text, Audio)

- Unceasing customer service

Track the below URL for one-step submission https://juniperpublishers.com/online-submission.php 